\title{
REVIEW
}

\section{Current ethical problems in cell biology}

\author{
Josef Berger \\ Faculty of Social and Health Studies, University of South Bohemia, České Budějovice, Czech Republic
}

Received $10^{\text {th }}$ July 2005.

Published online $2^{\text {nd }}$ September 2005.

\begin{abstract}
Summary
We selected important ethical conflicts of interest in current cell biology and which remain still unresolved: the use of human biological material, patents for biological material, cloning and use of stem cells, genetic engineering, onset of human life and death, and the use of vertebrate biomodels. New data from cell and molecular biology cannot facilitate the solution of such problems - on the contrary, they make these solutions more difficult. A solution may be found within the socio-cultural problems. Intensive research is necessary both to accomplish economical and medical benefit and to clarify ethical rules. Thus, essential cell biology seems to be the important part of education for non-life sciences students and students of biology and medicine would touch the social and ethical implications of recent biotechnologies in each knowledge-based economy.
\end{abstract}

Keywords: bioethics - quality control - cloning - toxicity - neuropharmacology - criminal and warlike misuse

\section{INTRODUCTION}

Ethics is that part of philosophy which concerns good behaviour; it is the theory of morality. Ethics searches common fundamentals for morality, it seeks a just morality. It applies certain philosophical approaches to human life and behaviour. Ethics is challenged by problems related to cultural, legal, religious and market regulations.

Bioethics studies questions bearing on progress in the life sciences; it is life-science ethics. It could be said that the practice of bioethics is re-

Josef Berger, Faculty of Health and Social Studies, University of South Bohemia, Branišovská 31, 37005 České Budějovice, Czech Republic berger@jcu.cz lated to survival as an effective social institution (Roy and Lambert 2000). Although it includes all levels of the hierarchy of the life organisation from cells to biosphere, recent bioethics seems to be focused on new biotechnologies in biomedicine, mainly in, but not limited to, cell and molecular biology (Berger 2003).

Great advances in cell biology have provoked a number of ethical studies. We can identify several areas within these topics: (i) the use of human biological material for research and (ii) for laboratory diagnosis, (iii) the clinical use of stem cells, (iv) the onset of human life, (v) anti-ageing research, (vi) the use of animal models in research, (vii) genetic engineering, (viii) patents for biological materials, (ix) biological weapons, and (x) education for ethical responsibility. 


\section{THE USE OF HUMAN BIOLOGICAL MATERIAL}

Human biologic material has been widely used for a long period for laboratory diagnostics in biochemistry, haematology, immunology, histopathology, molecular genetics, and cytopathology. To achieve the best laboratory diagnosis, internal and external quality control (Kazmierczak 2003, Lawson et al. 1988) is an unavoidable part of laboratory management. A quality control assessment covers (Znidarcic 2004) the frequent use of artificial standards, confidentiality of results, adequate staffing levels, appropriate reporting format and contents, and the relationships between clinicians.

The abuse of human biologic material concerns mainly reproductive biology and human cloning. Long-term experience has led to the formulation of widely accepted laws and regulations in many countries (Berger 2003). To eliminate risk, the use of human biologic samples for research and therapeutic cloning must subordinate the informed acceptance of the donor and their use for reproductive cloning is forbidden. Diverse cultural meanings are associated with biologic material which is considered waste tissue, typically the placenta (Jenkins and Sugarman 2005).

\section{STEM CELLS}

This topic generates a great deal of public interest; it is the aim of several theological studies. It covers both cloning and cell-replacement therapies.

Mitosis of stem cells either leads to selfrenewal or produces more differentiated cells (cf. Lakshmipathy and Verfaillie 2005). These more differentiated cells can also be stem cells, and knowledge of several types of stem cells has increased and others have yet to be discovered. Put simply, pluripotential stem cells are an origin for all cell populations in the organism, multipotential stem cells for several relative cell types (e.g. CFUGEMM for all blood lines), and unipotential/ committed progenitor stem cells for one cell population (e.g. BFU-E for red blood cells).

Several lines of stem cells have been discovered from germ cells, the embryo, foetus and adults (Bongso and Richards 2004, for review).

Embryonic stem cells are differentiated very slightly and they are, therefore, multipotential. Similarly, stem cells from the umbilical cord and placenta are also little differentiated and these tissues are interesting sources of cells for a therapeutical purpose. The research aim is to form new tissues or organs for transplantation. Ethical conflict concerning research into these cells emerges from the possibility of deriving synthetic gametes from embryonic stem cells (Testa and Harris 2005).

Exhaustive judgement of the role stem cells play in new therapies is at the recent level of their knowledge impossible and too early; much more biomedical basic research is still needed. Nevertheless, this field of cell therapy seems to be promising after taking into account the evaluation of any undesired medical side effects.

\section{THE ONSET OF HUMAN LIFE}

Each living cell represents a living entity. Thus, the questions arise: which cells and how many cells form the onset of a human being?

Almost every somatic cell can form a new human subject, as it contains full genetic information. A short part of the DNA in older somatic cells is changed or damaged and future molecular genetics may reveal if these changes would limit cloning. We are far from having knowledge of the details and singularity of the mechanism of DNA transfer in oogenesis, and spermiogenesis and current research concerning mammalian cloning resembles blindman's buff; that is why we are certain of the death of most embryos and the formation of heavily injured organisms. Recent biologic knowledge documents the fact that current human cloning using somatic cells is, therefore, discordant with the ethical base of juridical systems that protect human life and health.

The zygote is the cell which could be considered to be a human subject. Nevertheless, the zygote is also an entity composed of spermatozoon and oocyte components before nuclear syngamy; inseparable union follows (Tesarik and Greco 2004). The application of embryo protection laws from the nuclear syngamy stage onwards is not motivated by the results of current biological research which still does not explain if only genetic information in nucleic acids sufficiently defines the individuality of a human subject; we do not know so far exactly how many cells represent the human being.

Epigenetic information also seems to be an essential element of the program of development together with DNA (Alonso 2004). Epigenetic factors make new structures, which originate during ontogenesis, are not preformed but adopt specific values. Various factors can also change within certain limits many of the biological characteristics of a human subject, from birth and for the rest of his life - this is well known because of for example the differences between one-egg twins.

The conflict concerning the definition of the onset of the human being has two limits: it starts either (i) after the birth of a viable child or (ii) after 
the nuclear syngamy in the zygote. Biology and medicine are still improving the possibilities for the survival of children born untimely, in the future perhaps towards the zygote. Biology does not offer a definition of the point in time when the new human being originates. Such definition cannot be a result of biological laboratory experiments, and it seems that better knowledge of living systems does not support discovery of this definition. The jurists' point of view concerning the protection of human life, the control of therapeutic cloning and embryological research (Lenoir 2002) must be constituted on socio-cultural factors.

\section{ANTI-AGEING RESEARCH}

We covet a long life without health problems. Both life span and life quality can also be ameliorated by the results of cell biology, including oxidative stress as well as cellular and molecular replacement interventions. The following six ethical arguments against anti-ageing medicine can be evaluated (Mackey 2003): (i) the poor die young while the rich refuse to age, (ii) denying ageing's immutability, (iii) dominating nature, altering and comodifying ourselves, (iv) overpopulation, (v) with no natural deadline, life itself outlives its value, and (vi) prejudice against the old and the young.

It seems that gerontological research should be regulated within the framework of disease reduction and a longer, fuller, and more meaningful life (Mackey 2003). Broadly speaking this the purpose of all medical therapies, and greater expectations are offered mainly by oncology and immunology (Bauer 2005, Caruso et al. 2004).

Unique technological and ethical questions are presented by neurosciences as they search mechanisms of brain functioning to prevent the neurodegenerative process or to eliminate other injuries to interneuronal communications. Nanotechnology and neuropharmacology will therapeutically modify transmitter functions in the brain (Greenfield 2005). This scientific progress will offer the possibility of non-therapeutical changes in human behaviour for both criminal and warlike misuse. We are not exploring how we could both eliminate the above mentioned eventual misapplication of the technology and at the same time retain the expected benefit.

\section{ANIMAL MODELS}

Most biomedical studies, particularly preclinical evaluations of adverse effects (Kinter and Valentin
2002), are carried out on rats and mice, some experiments on larger animals such as dogs, rabbits, guinea-pigs, or monkeys. Selective inbreeding has produced genetically and physiologically stable strains as well as strains which are considered reasonable biomodels of certain human disorders. Some disorders are induced in animals by special surgical procedures, by toxin administration, and by molecular biological techniques resulting in knock-in, generalised knock-out and tissue-specific knockout animals (cf. Levine et al. 2004, Rees and Alcolado 2005).

Animal experimentation is, in many countries, subject to legal restrictions (Brashaw 2002, Kromka 2003) reflecting various cultural, ethical, political, and economic influences.

The discrepancy between the results obtained in studies evaluating the therapeutical efficiency of newly developed drugs on animals with various cancers, and clinical evaluations performed on cancer patients showed that histological and cytological similarities between animal and human tumours are not sufficient to obtain good predictions from animal studies. Currently, the disclosure of genetical and molecular similarities constitutes an indication for us to use better animal cancer models (Porrello et al. 2004).

Alternative biomodels represent all the technologies able to replace animal experimentation, e.g. cell, tissue and cultures. The use of human cells in biomedical research and testing has the advantage over the use of laboratory animals due to the presence of more-relevant morphological and physiological properties (Combes 2004). There are are considerable number of uses for cells which have been derived from tumours. Ethical problems also originate from the use of primary cell cultures where sources are cadavers, diseased tissue, skin trips, blood, bucal cavity, hair follicles and surgical waste from biopsies (Combes 2004).

Alternative methods are able to lessen our reliance on the use of vertebrates and consequently improve our status in relation to animal ethics although they cannot totally replace animal experiments (Adolphe 1995). There are complementary rather than "alternative" models which are used mainly, but not exclusively, for the screening of new xenobiotics. Despite the progress in using in vitro models, which accelerate the development of new therapeutic procedures and lower the cost of safe preclinical evaluations, animal models remain necessary on the grounds of absence of knowledge of many physiological regulations. Invertebrate animals could be new alternative models (Berger et al. 2003). 


\section{GENETIC ENGINEERING}

Genetic engineering is a major scientific and technological revolution. Genetic modifications can represent risks for human health, animal welfare and the environment (Weaver and Morris 2005, for review). Risks concerning gene therapy are similar to those of stem cell therapies and eventually, restrictive procedures will be similar to those required before tissue or organ transplantation. We could better eliminate such risks by acquiring better knowledge concerning gene regulation in the human body. The risks concerning unstable transgene and vectors, reflects unpredictable interactions between the transgene and host genome.

One of the greatest issues to be faced is with genetically modified foods. Although there is a major conflict in Europe, scepticism is very useful as was revealed for new xenobiotics synthesised in the $20^{\text {th }}$ century. As with any new drug in development, gene transfer food or biotechnologyderived pharmaceuticals have to be tested for their potential toxicity in preclinical studies (Christ 2002) including biochemical, haematological, immunological, histological and special examinations. As safety evaluation on animal models does not provide the same data as following administration to human subjects, the stage of clinical tests on volunteers can eliminate the risk of undesirable effects.

\section{BIOMEDICINE PATENTING}

Over the last two decades, the ethical implications of patents for biological materials and processes have been the subject of public debate (Crespi 2005). Copyrights, trademarks etc. are widely acceptable. The patent system can evoke the legal protection of inventions in life sciences.

\section{BIOLOGICAL WEAPONS}

Microorganisms which are specifically modified, could be newly developed for military use. Efforts to strengthen the Biological Weapons Convention with a legally binding compliance protocol (Nixdorf and Bender 2002) is activity which promises to achieve results currently, although the full destruction of all biological military samples and weapons is only moral human behaviour.

\section{EDUCATION FOR ETHICAL RESPONSIBILITY}

Learning the important topics from experimental biology can be part of the nation's strategic move towards a knowledge-based economy where the life sciences are poised as a new engine for economic growth (Lim 2003). Students of secondary/high schools would have also lectures about mammalian cloning, stem cells, sex selection and environmental hormone mimics.

At the university level, details on these topics, reproductive technologies and gene therapy seem to be an important part of a broader course which caters for students not majoring in the life sciences. Students of biology and medicine would touch the social and ethical implications of recent technologies, which enable scientists to manipulate life; two teaching models concerning the possible consequences of biology and biomedicine (Gilbert and Fausto-Sterling 2003) can be used: (i) to integrate social issues into the laboratory portion of the curriculum or (ii) to synthesise social contexts into specialised courses.

\section{CONCLUSION}

Ethical conflicts of interest in modern cell biology represent the greatest part of current bioethics. The expectation that new data in cell and molecular biology offer their solution seems to be erroneous as processes in living systems are interconnected. Whilst a little knowledge makes it possible for us to see virtual borders, new results in biology dissolve them among physiological and morphological phenomena. New biotechnologies demand new ethical and legal rules and this not a biological or medical problem, but a socio-cultural one. Thus, essential cell biology seems to be an important part of education for both life-science and non-life science students in all knowledge-based economies.

\section{ACKNOWLEDGEMENTS}

This work was partially supported by grant no 257/05 from the Ministry of Education of the Czech Republic.

Simultaneously published in J. Berger (ed): Advances in Cell and Molecular Biology. Kopp Publ., České Budějovice 2005, pp. 1-11. 


\section{REFERENCES}

Adolphe M.: Les méthodes dites alternatives à l'experimentation animale. Problèmes scientifiques et ethiques. Bull. Acad. Nat. Med. 179: 1109-1119, 1995.

Alonso C.: An ontological view of the human embryo. A paradigm. Eur. J. Endocrinol. 151: Suppl. 3, U17-U24, 2004.

Bauer M.E.: Stress, glucocorticoids and ageing of the immune system. Stress 8: 69-83, 2005.

Berger J.: Ethical conflicts of interest in modern biomedicine? J. Appl. Biomed. 1: 181-182, 2003.

Berger J., Walczysko S., Pávková J., Gutzeit H.O.: Effects of genistein on insect haemocytes. J. Appl. Biomed. 1: 161-168, 2003.

Bongso A., Richards M.: History and perspective of stem cell research. Best Pract. Clin. Obst. Gynaecol. 18: 827-842, 2004.

Bradshaw R.H.: The ethical review process in the UK and Australia: The Australian experience of improved dialogue and communication. Anim. Welfare 11: 141-156, 2002.

Caruso C., Lio D., Cavallone L., Franceschi C.: Aging, longevity, inflammation, and cancer. Ann. N.Y. Acad. Sci. 1028: 1-13, 2004.

Christ M.: Preclinical evaluation of gene transfer products: safety and immunological aspects. Toxicology 174: 13-19, 2002.

Combes R.D.: The use of human cells in biomedical research and testing. ATLA 32: Suppl 1A, 43-49, 2004.

Crespi R.S.: Ethico-legal issues in biomedicine patenting: a patents professional viewpoint. Sci. Engin. Ethics 11: 117-136, 2005.

Gilbert S.F., Fausto-Sterling A.: Educating for social responsibility: changing the syllabus of developmental biology. Int. J. Dev. Biol. 47: Sp. Iss., 237-244, 2003.

Greenfield S.A.: Biotechnology, the brain and the future. Trends Biotechnol. 23: 34-41, 2005.

Jenkins G.L., Sugarman J.: The importance of cultural considerations in the promotion of ethical research with human biologic material. J. Lab. Clin. Med. 145: 118-124, 2005.

Kazmierczak S.C.: Laboratory quality control: using patient data to assess analytical performance. Clin. Chem. Lab. Med. 41: 617627, 2003.

Kinter L.B., Valentin J.P.: Safety pharmacology and risk assessment. Fund. Clin. Pharmacol. 16: 175-182, 2002.
Kromka F.: Equality for man and animal - a common-sense criticism of this animal rights concept. Ber. Landwirt. 81: 150-158, 2003.

Lakshmipathy U., Verfaillie C.: Stem cell plasticity. Blood Rev. 19: 29-38, 2005.

Lawson N.S., Gilmore B.F., Tholen D.W.: Multiprogram characterization of laboratory bias, precision, and total error - proposal for improved assessment with shared external and expanded internal (regional) quality-control pools. Arch. Pathol. Lab. Med. 112: 454-461, 1988.

Lenoir N.: Bioéthique et XXIe siècle, le point de vue du juriste. Presse Méd. 31: 565-571, 2002.

Levine M.S., Cepeda C., Hickey M.A., Fleming S.M., Chesselet M.F.: Genetic mouse models of Huntington's and Parkinson's diseases: illuminating but imperfect. Trends Neurosci. 27: 691-697, 2004.

Lim T.M.: Learning developmental biology has priority in the life sciences curriculum in Singapore. Int. J. Dev. Biol. 47: Sp. Iss., 1171212003.

Mackey T.: An ethical assessment of anti-aging medicine. J. Anti-Aging Med. 6: 187-204, 2003.

Nixdorf K., Bender W.: Ethics of university research, biotechnology and potential military spin-off. Minerva 40: 15-35, 2002.

Porrello A., Cardelli P., Spugnini E.P.: J. Exper. Clin. Cancer Res. 23: 181-193, 2004.

Rees D.A., Alcolado J.C.: Animal models of diabetes mellitus. Diabet. Med. 22: 359-370, 2005.

Roy D.J., Lambert R.D.: L'éthique des sciences de la vie: à un carrefour? Médecine/Sciences 16 : 1192-1197, 2000.

Tesarik J., Greco E.: A zygote is not an embryo: ethical and legal considerations. Reprod. Biomed. Online 9: 13-16, 2004.

Testa G., Harris J.: Ethics and synthetic gametes. Bioethics 19: 146-166, 2005.

Weaver S.A., Morris M.C.: Risks associated with genetic modification: an annotated bibliography of peer reviewed natural science publications. J. Agr. Environm. Ethics 18: 157$189,2005$.

Znidarcic Z.: Ethical problems in cytology. Cytopathology 15: 49-52, 2004. 